\title{
Helminthic infection in three native rodent species from a semiarid Mediterranean ecosystem
}

\author{
Infecção por helmintos em três espécies de roedores nativos em um ecossistema mediterrâneo \\ Andrea Yáñez-Meza $^{1}$ (D); Carlos Landaeta-Aqueveque ${ }^{2}$ (D); Nicol Quiroga ${ }^{1}$ (D); Carezza Botto-Mahan ${ }^{1}$ (D) \\ ${ }^{1}$ Departamento de Ciencias Ecológicas, Facultad de Ciencias, Universidad de Chile, Santiago, Chile \\ ${ }^{2}$ Departamento de Patología y Medicina Preventiva, Facultad de Ciencias Veterinarias, Universidad de Concepción, Concepción, Chile
}

Received October 23, 2018

Accepted February 6, 2019

\begin{abstract}
Helminth parasites are still not a well-known component of animal biodiversity. In this study, we describe and compare the endoparasite assemblages of three native rodent species from a semiarid Mediterranean ecosystem. A total of eight species of gastrointestinal helminth parasites were detected. The endoparasitic communities of the rodents Phyllotis darwini (5 species), Octodon degus (4 species), and Abrothrix olivaceus (3 species) were described in terms of their prevalence and mean abundance. In addition, endoparasite records by rodent species were submitted to rarefaction analyses to verify sampling robustness and used to compare richness and similarity among rodent species. $O$. degus presented the highest prevalence and parasitic load, but was of low diversity, while $P$. darwini presented the highest diversity, but had a low prevalence rate. Conversely, A. olivaceus presented the lowest prevalence and diversity. This study contributes to the existing knowledge of the endoparasitic fauna of rodent species from semiarid Mediterranean zones.
\end{abstract}

Keywords: Endoparasites, Syphacia phyllotios, Helminthoxys gigantea, Litomosoides pardinasi, Heteroxynema chiliensis, Gongylonema sp.

\section{Resumo}

Os helmintos parasitas não são um componente ainda bem conhecido da biodiversidade animal. Neste trabalho, descreveu-se e comparou-se as redes de endoparasitas de três espécies de roedores nativos de um ecossistema mediterrâneo semiárido. No estudo foram detectadas um total de oito de espécies de helmintos gastrointestinais parasitas. As comunidades endoparasíticas dos roedores Phyllotis darwini (5 espécies), Octodon degus (4 espécies) e Abrothrix olivaceus (3 espécies) foram descritas por meio da sua prevalência e abundância média. Além disso, os registros de endoparasitas achados nas diferentes espécies de roedores foram submetidos a uma análise de rarefação para verificar a robustez da amostragem, e utilizados para comparar a riqueza e a similaridade entre espécies de roedores. Octodon degus apresentou a maior prevalência e carga parasitária, menor diversidade, enquanto $P$. darwini apresentou a maior diversidade, mas uma baixa prevalência. Porém, A. olivaceus apresentou a menor prevalência e diversidade de parásitas. Este estudo representa uma contribuição ao conhecimento da fauna endoparasitária das espécies de roedores próprias das zonas semi-áridas do Mediterrâneo chileno.

Palavras-chave: Endoparasitas, Syphacia phyllotios, Helminthoxys gigantea, Litomosoides pardinasi, Heteroxynema chiliensis, Gongylonema sp.

\section{Introduction}

In Chile, mastozoological research has primarily concentrated on small mammal species (Muridae, Octodontidae, and Didelphidae), but studies on their helminth fauna have been poorly addressed (COFRÉ \& VILINA, 2008). Helminthology research on rodents began more than a century ago (POUPIN, 1897); however, articles on this topic are scarce, most of which have adopted a taxonomic approach (ÁLVAREZ, 1960; DENKE \& MURÚA,

*Corresponding author: Carezza Botto-Mahan. Departamento de Ciencias Ecológicas, Facultad de Ciencias, Universidad de Chile, Las Palmeras, 3425, Nuñoa, Santiago, Chile. e-mail: cbotto@uchile.cl
1977; ALCAÍNO \& GORMAN, 1990) and only occasionally provided a description of the ecological background (CATTAN et al., 1992; LANDAETA-AQUEVEQUE et al., 2018). Given that the Chilean territory is a biogeographic island, the assembly of rodents (and their parasites) has resulted from historical interactions and ecological factors on several temporal scales (CATTAN et al., 1992; LANDAETA-AQUEVEQUE et al., 2014a, 2018).

The study of the quantitative traits of the parasitic communities of native rodent species, particularly in localities with low impacts of introduced or invasive species, enables the generation of 
baseline knowledge of helminth communities for future studies, especially within the context of global change. However, within endoparasitic systems, the total assembly richness inside a host species tends to be underestimated because of the low detectability of this type of parasites, imposing a strong bias when describing and quantifying the complete set of parasite-host interactions inside a community. To solve this problem, accumulation curves have been designed based on complex statistical models to predict the number of species found by sampling with a degree of certainty (COLWELL et al., 2004, 2012; COLWELL, 2005). Although this tool is not new, its use in parasitic assemblages is relatively novel, with only a few studies including this type of analysis (RAMOS et al., 2012).

The Chilean semiarid-Mediterranean ecosystem presents most rainfall concentrated in the winter season (June to August), with a mean annual precipitation of $185 \mathrm{~mm}$ and with ample annual variation, alternating between long droughts and unusual years of high rainfall $(-350 \mathrm{~mm})$ (LIMA et al., 2006). This ecosystem is characterized by low vegetation cover, mainly represented by shrubs, cactus species and sclerophyllous forests, and lower terrestrial mammal richness than other areas with similar climate (LACHER \& MARES, 1986). In this ecosystem, 25 native mammal species have been described and 36\% of them are rodents, the most common and abundant group (IRIARTE, 2008). Scarce information on the endoparasitic fauna of rodent species has been reported (but see QUENTIN et al., 1979; CATTAN et al., 1992; LANDAETA-AQUEVEQUE et al., 2007a). In this study, we examined the helminth infection in three rodent species: a hystricomorph (Octodon degus, the brush-tailed rat) and two myomorphs (Phyllotis darwini, Darwin's leaf-eared mouse; and Abrothrix olivaceus, the olive grass mouse), the most abundant rodent species in semiarid
Mediterranean Chile. These species were from a protected area, Las Chinchillas National Reserve, characterized by low levels of anthropic disturbance, cattle and introduced animals. The aim of this study is to contribute to the existing knowledge of the helminth parasite communities of three rodent species from semiarid Mediterranean zones, using traditional parasitic parameters (prevalence and mean abundance) and diversity of endoparasitic gastrointestinal species estimations.

\section{Materials and Methods}

\section{Rodent sampling and autopsy}

Rodent trapping was performed during the summer seasons of 2008 to 2013 at Las Chinchillas National Reserve (31 ${ }^{\circ} 28^{\prime} \mathrm{S}$, $71^{\circ} 03^{\prime} \mathrm{W}$, Coquimbo Region, Chile; Figure 1), using wire mesh live-animal traps (collapsible Sherman traps of $24 \times 8 \times 9 \mathrm{~cm}$; FORMA, Santiago, Chile) baited with rolled oats and equipped with cotton bedding. Traps were set $10 \mathrm{~m}$ apart, covering a total area of $3.39 \mathrm{ha}$, and opened at dusk (19:00 h) until the next morning (09:00 h) during four to five nights each sampling year. Only captured animals over $20 \mathrm{~g}$ (sub-adult and adult specimens of $P$. darwini and $A$. olivaceus, and of all ages for $O$. degus) were brought to a field laboratory, where they were euthanized with an overdose of isoflurane. Capturing and handling procedures met the guidelines of the American Society of Mammalogists (SIKES \& GANNON, 2011), and were approved by the Ethical Committee of the Faculty of Science of the University of Chile, the Chilean Agriculture and Livestock Bureau (SAG) and the National Forest Corporation (CONAF).
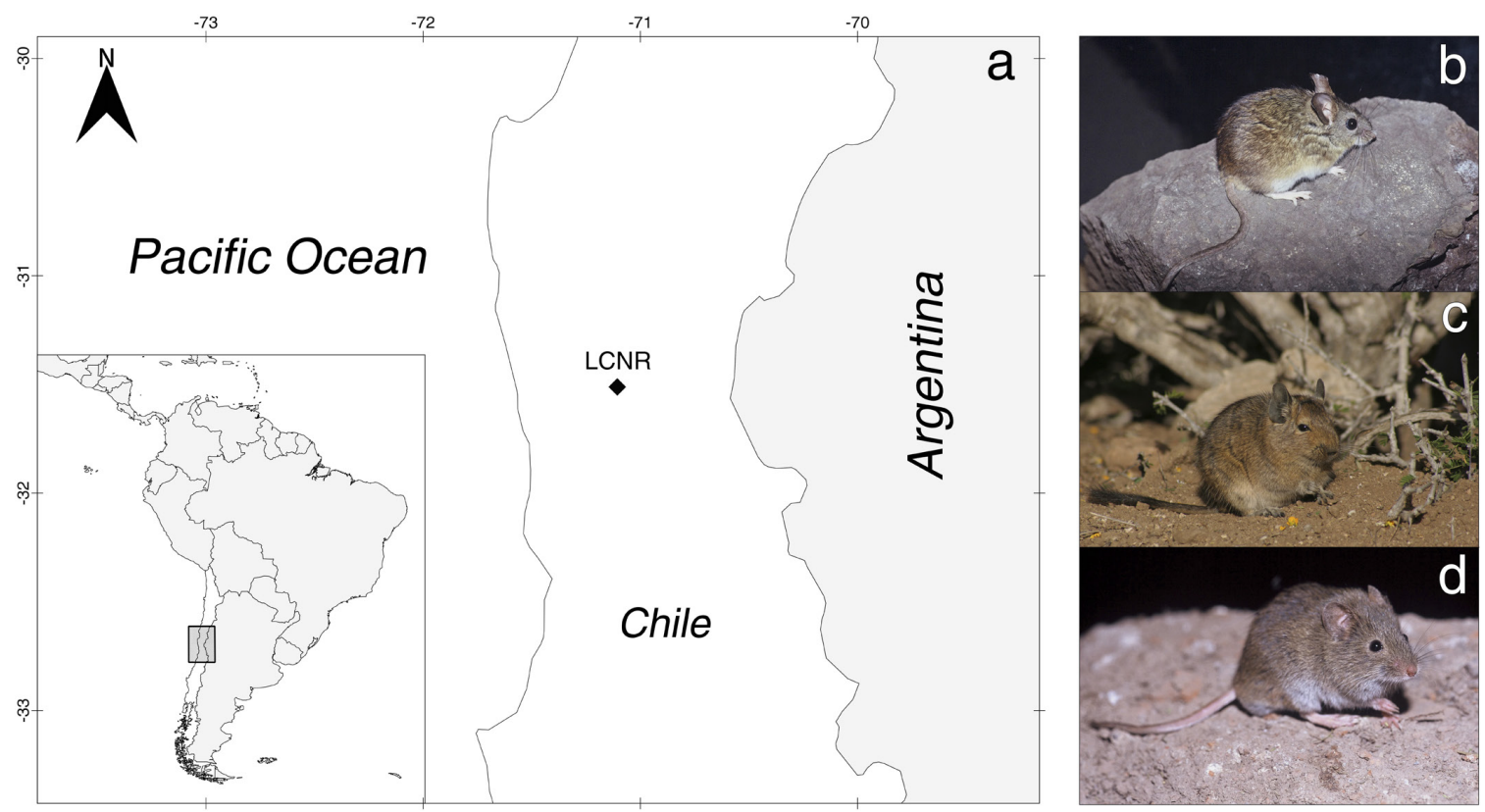

Figure 1. a) Map of north-central Chile with the geographic distribution of Las Chinchillas National Reserve (black diamond), b) Phyllotis darwini, c) Octodon degus and d) Abrothrix olivaceus. Photographs by Mariana Acuña-Retamar. 
In each specimen, we used dissecting scissors to perform a horizontal abdominal incision cutting only the skin. Then, we opened the muscle layer separating the viscera from the abdomen internal wall, keeping the gastrointestinal content intact. We performed a second perpendicular incision, respect to the first one, up to the thoracic level and toward caudal following the groin line (inverted "Y" shaped incision), entering to the abdominal and thoracic cavities. We performed a visual examination for helminths in these cavities, then the digestive tube was released and preserved in $90 \%$ ethanol.

\section{Helminth collection and identification}

The digestive tube was sectioned in stomach, small intestine, large intestine and cecum, and each section longitudinally opened for inspection. The lumen, mucous, and sub-mucous membrane of each section were meticulously examined for helminths under stereomicroscope (Motic, DMW-143-FBGG). Helminths were counted and preserved in 70\% ethanol (LANDAETA-AQUEVEQUE et al., 2007a), then cleared in glycerinated ethanol and observed under an optic microscope (Primo Star; Zeiss, Oberkochen, Germany). The isolated species were identified using the methods described in the literature (BABERO \& CATTAN, 1975; BABERO et al., 1975; QUENTIN et al., 1975, 1979) and by following the advice of expert taxonomists of the Facultad de Ciencias Veterinaria, Universidad de Concepción.

\section{Description of helminth communities and statistical analyses}

Mean abundance $(\mathrm{MA}=$ the number of isolated parasites divided by the number of analyzed hosts) was estimated following the methods of Bush et al. (1997), and prevalence ( $\mathrm{P}=$ the number of individuals of a host species infected with a specific parasite species divided by the number of hosts examined) was estimated following the approach of Margolis et al. (1982). Additionally, rarefaction analyses were performed to compare observed and estimated species richness using 100 randomization models, which were extrapolated to a total of 500 samples using the formula corrected by bias Chao1 and Chao2, which included the upper limit to be considered as a rare species $(R=2)$. Chao 2 was chosen as the best estimator of the asymptotic richness for our data based on samples (Bernoulli Product Model) (COLWELL et al., 2012). The convergence in the accumulation curve of the estimated richness (Sest) and the chosen richness estimator (Chao2) in terms of their maximum values was used to corroborate that the sampling size was appropriate for describing parasite community richness. Finally, the Shannon index of diversity $\left(\mathrm{H}^{\prime}\right)$ was used to estimate diversity, and the Jaccard similarity index $(\mathrm{J})$ was adopted to estimate sharing species. Both the rarefaction analyses and index estimations were performed using EstimateS 9.1.0 software (COLWELL, 2005). Estimated richness (Sest) and Shannon diversity indexes ( $\left.\mathrm{H}^{\prime}\right)$ were compared between pairs of host species by Student's t-test with Bonferroni correction, given that the EstimateS software also provides the standard deviation (SD) for each estimated index. Overall prevalence among rodent species and prevalence of different endoparasite species within hosts were compared by Chi-square tests (SOKAL \& ROHLF, 1995).

\section{Results}

A total of 134 small mammals belonging to three rodent species were analyzed: $P$. darwini ( $\mathrm{n}=85$; 46 males and 39 females), $O$. degus ( $\mathrm{n}=27 ; 14$ males and 13 females), and $A$. olivaceus ( $\mathrm{n}=22 ; 14$ males and 8 females). From these rodent species, a total of 750 worms belonging to eight different helminth species were collected: four species in $O$. degus, five in $P$. darwini and three in A. olivaceus (see Table 1). Helminth species were consistently detected in specific digestive tract sections: Heteroxynema chiliensis in the caecum and colon; Helminthoxys gigantea, Syphacia phyllotios, and Trichuris bradleyi in the caecum; Pterygodermatites (Paucipectines) sp. in the small intestine and Gongylonema sp. in the stomach; and Litomosoides pardinasi and Acanthocheilonema sp. outside the digestive tract.

The results of the rarefaction analyses are summarized in Table 2, in which the value of the asymptotic species richness (Sest) is shown, as well as the best predictor of richness is estimated with their 95\% confidence intervals (Chao2). The observed richness

Table 1. Endoparasite species in their host species and their site of infection inside the digestive tract.

\begin{tabular}{|c|c|c|c|c|}
\hline Host species & Endoparasite species & Site of infection & P\% (CI 95\%) & $\mathrm{MA} \pm \mathrm{SE}$ \\
\hline \multirow[t]{4}{*}{ Octodon degus } & Heteroxynema chilensis & Caecum and colon & $25.93(11.87-46.59)$ & $1.37 \pm 0.89$ \\
\hline & Helminthoxys gigantea & Caecum lumen & $88.89(69.7-97.09)$ & $12.30 \pm 3.38$ \\
\hline & Pterygodermatites (Paucipectines) sp. & Small intestine & $3.70(0.19-20.89)$ & $0.11 \pm 0.11$ \\
\hline & Trichuris bradleyi & Caecum lumen & $3.70(0.19-20.89)$ & $0.15 \pm 0.15$ \\
\hline \multirow[t]{5}{*}{ Phyllotis darwini } & Syphacia phyllotios & Caecum lumen & $12.94(6.95-22.39)$ & $1.54 \pm 1.17$ \\
\hline & Gongylonema sp. & Stomach & $11.76(6.09-21.01)$ & $0.99 \pm 0.63$ \\
\hline & Pterygodermatites (Paucipectines)sp. & Small intestine & $8.24(3.66-16.76)$ & $0.13 \pm 0.05$ \\
\hline & Acanthocheilonema sp. & Outsite digestive tract & $4.71(1.52-12.27)$ & $0.05 \pm 0.02$ \\
\hline & Litomosoides pardinasi & Outsite digestive tract & $9.41(4.44-18.20)$ & $0.27 \pm 0.12$ \\
\hline \multirow[t]{3}{*}{ Abrothrix olivaceus } & Helminthoxys gigantea & Caecum lumen & $9.09(1.59-30.62)$ & $0.18 \pm 0.14$ \\
\hline & Syphacia phyllotios & Caecum lumen & $13.64(3.59-35.96)$ & $2.09 \pm 1.95$ \\
\hline & Gongylonema sp. & Stomach & $18.18(5.99-41.1)$ & $3.23 \pm 2.85$ \\
\hline
\end{tabular}

P: prevalence; CI: confidence interval; MA: mean abundance; SE: standard error. 
(Sobs) coincided with Sest for the analyses in $P$. darwini and $A$. olivaceus, reaching the asymptote in the sample numbers of 62 and 20, respectively. In the case of $O$. degus, the asymptotic richness exceeded the observed richness, so the total helminthic assembly in this rodent species would be found by analyzing 92 specimens. The highest Sest $( \pm \mathrm{SD})$ was observed in $P$. darwini $(5 \pm 0.01)$, followed by $O$. degus $(4.96 \pm 0.88)$ and $A$. olivaceus $(3 \pm 0.01)$ (Figure 2$)$. Only $A$. olivaceus exhibited statistically significant differences with $P$. darwini and $O$. degus in terms of estimated richness ( $P<0.001$ for both paired comparisons).

The highest species diversity $( \pm S D)$ was observed in the component community of $P$. darwini $(1.13 \pm 0.01)$, followed by $A$. olivaceus $(0.79 \pm 0.1)$ and $O$. degus $(0.42 \pm 0.04)$. The three species of rodents exhibited statistically significant differences in their diversity indexes $(P<0.0001$ for all paired comparisons). The most similar component communities were those of $P$. darwini and $A$. olivaceus. The most dissimilar communities were those of $P$. darwini and $O$. degus. See Table 3 for details related to the species diversity (Shannon index, H') and similarity (Jaccard index, J) indexes.

Overall, $O$. degus exhibited a significantly higher global prevalence of endoparasites $(92.86 \%)$ than $P$. darwini $(37.65 \%)\left(\chi_{(1)}^{2}=28.23\right.$, $P<0.001)$ and $A$. olivaceus $(36.36 \%)\left(\chi_{(1)}^{2}=20.50, P<0.001\right)$, but no difference was detected between $P$. darwini and $A$. olivaceus $\left(\chi_{(1)}^{2}=0.01, P=0.912\right) . P$. darwini exhibits the highest richness, as it has five endoparasite species, with S. phyllotios (12.94\%) and Gongylonema sp. (11.76\%) being the most prevalent, closely followed by Litomosoides pardinasi, Pterygodermatites (Paucipectines) sp., and Acanthocheilonema sp. We did not detect statistically significant differences among the endoparasitic prevalences of this rodent species $\left(\chi_{(4)}^{2}=4.14, P=0.387\right)$. In the case of $A$. olivaceus, the species with the highest prevalence and mean abundance were Gonglyonema sp. (18.18\% and 3.23, respectively) and S. phyllotios (13.64\% and 2.09 , respectively), followed by a lower frequency of Helminthoxys gigantea, but again we did not detect statistically significant differences in their prevalence $\left(\chi_{(2)}^{2}=0.772, P=0.680\right)$.

Table 2. Number of rodents analyzed (n), observed richness (Sobs), asymptotic richness of species (Sest) and the best estimator of richness (Chao2) for the endoparasite assemblages of each species.

\begin{tabular}{ccccl}
\hline Endoparasites & $\boldsymbol{n}$ & Sobs & Sest & Chao2 (CI 95\%) \\
\hline Phyllotis darwini & 85 & 5 & 5 & $5.02(5.00-6.04)$ \\
Abrothrix olivaceus & 22 & 3 & 3 & $3.05(2.99-5.84)$ \\
Octodon degus & 27 & 4 & 4.96 & $4.96(4.07-16.84)$ \\
\hline
\end{tabular}

CI: Confidence interval. An interval estimate computed from the statistics of the observed data, that might contain the true value of an unknown population parameter.

Table 3. Estimates of Shannon indexes (H', on the diagonal highlighted in grey), Jaccard indexes ( $\mathrm{J}$, above the diagonal), and the number of shared species (under the diagonal).

\begin{tabular}{cccc}
\hline & $\begin{array}{c}\text { Phyllotis } \\
\text { darwini }\end{array}$ & $\begin{array}{c}\text { Abrothrix } \\
\text { olivaceus }\end{array}$ & $\begin{array}{c}\text { Octodon } \\
\text { degus }\end{array}$ \\
\hline Phyllotis darwini & 1.13 & 0.333 & 0.125 \\
Abrothrix olivaceus & 2 & 0.79 & 0.16 \\
Octodon degus & 1 & 1 & 0.42 \\
\hline
\end{tabular}

In the community of $O$. degus, $H$. gigantea had a remarkable prevalence, infecting $88.89 \%$ of the analyzed specimens, followed by far by the other endoparasite species, detecting statistically significant differences in the enodoparasite species prevalences $\left(\chi_{(3)}^{2}=61.92, P<0.001\right)$. See details in Table 1 and Figure 3.

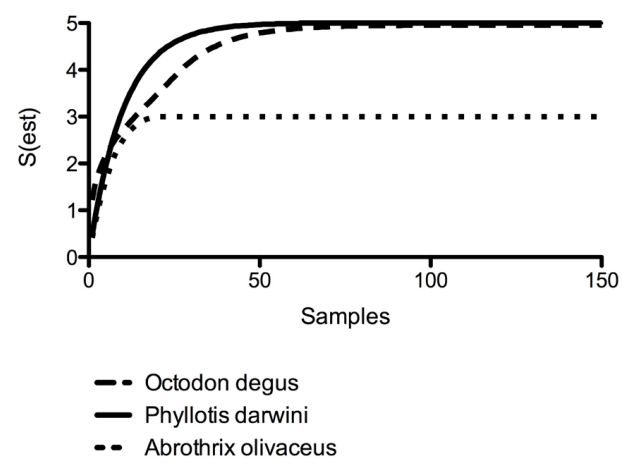

Figure 2. Extrapolation of the species-accumulation curves of the endoparasite assembly for Octodon degus (dashed line), Phyllotis darwini (continuous line), and Abrothrix olivaceus (dotted line).
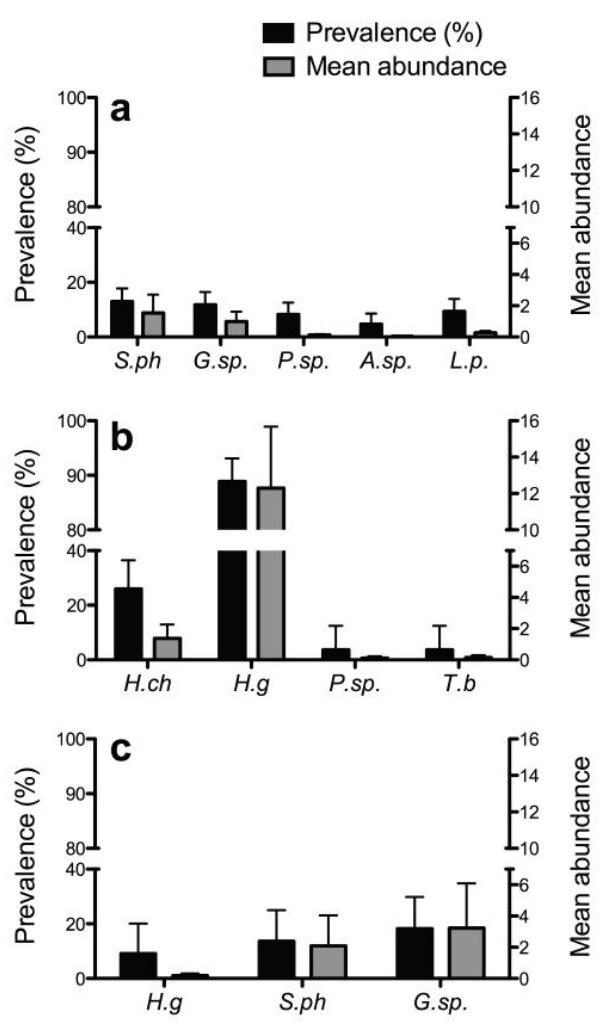

Figure 3. Prevalence (black bars) and mean abundance (grey bars) of infection of endoparasite species in a) Phyllotis darwini, b) Octodon degus, and c) Abrothrix olivaceus. H.g, Helminthoxys gigantea; H.ch, Heteroxynema chiliensis; P.sp., Pterygodermatites (Paucipectines) sp.; G.sp., Gongylonema sp.; S.ph, Syphacia phyllotios; L.p, Litomosoides pardinasi; A.sp., Acanthocheilonema sp.; and T.b, Trichuris bradleyi. Vertical lines represent \pm 1 standard error. 


\section{Discussion}

Within wildlife research, rodent species present the largest sets of parasitic studies. However, the endoparasitic communities of Chilean rodents are poorly evaluated from an ecological and quantitative approach (but see LANDAETA-AQUEVEQUE et al., 2007a,b, 2018), and only a few studies have been carried out in localities free of allochthonous rodents (CATTAN et al., 1992). In this study, by means of an extensive and intensive collection covering a long sampling period (2008-2013), we processed and identified helminths found in three native rodent species from a semiarid Mediterranean zone of Chile and described their gastrointestinal endoparasite assemblages.

\section{New host-helminth associations}

The following helminth species had not been previously found in P. darwini: (i) Gongylonema sp. (previously described in Abrothrix longipilis), (ii) Pterygodermatites (Paucipectines) sp. (genus described in A. olivaceus; CATTAN et al., 1992), and (iii) Aconthocheilonema sp. We highlight the presence of the filarial Litomosoides pardinasi in $P$. darwini, described as the first record in Chilean rodents and the second report of this helminth species all over the world (LANDAETA-AQUEVEQUE et al., 2014b). The following helminth species had not been previously found in A. olivaceus: (i) S. phyllotios (previously described in P. darwini; QUENTIN et al., 1979), (ii) Gongylonema sp., a genus previously recorded in $A$. longipilis (CATTAN et al., 1992) and in Rattus sp. (RUIZ DEL RÍO, 1939), and (iii) H. gigantea. Only Pterygodermatites (Paucipectines) sp. had not been previously found in $O$. degus.

It is interesting to note the high degree of specialization in endoparasites, as they are not only very consistent in their associations with a host species, but they also colonize specific areas of the digestive tract (Table 1), which is partially consistent with previous studies describing the specific site of helminth colonization (BABERO \& CATTAN, 1975; LANDAETA-AQUEVEQUE et al., 2007a,b, 2014b).

\section{Ecological inferences}

As expected, diversity indexes in semiarid Mediterranean ecosystems tended to be low, so it is not surprising that the most diverse assemblage of endoparasites reached only an $\mathrm{H}^{\prime}$ value of 1.13 (for $P$. darwini). The pair of host species with the most similar assemblages was $P$. darwini- $A$. olivaceus, sharing $33.3 \%$ of their assembly, while the most dissimilar pair was $P$. darwini-O. degus, sharing only $12.5 \%$ of their assembly. These results may have been observed because some host species are more phylogenetically related than others. Indeed, phylogenetical relatedness has been previously associated with the similarity of helminth communities of these rodent species (CATTAN et al., 1992; WELLS et al., 2015; YOUNG et al., 2017).

Our results showed that the endoparasitic prevalence in $O$. degus was $96.3 \%$, while for $P$. darwini and $A$. olivaceus it only reached
$37.6 \%$ and $36.4 \%$, respectively. Moreover, parasitic loads were considerably higher in $O$. degus than in the other two rodent species. $O$. degus presents a highly social behavior that is characterized by the construction of burrows, strong family ties, and allogrooming (FULK, 1976). This behavior could contribute to infection and reinfection processes among the members of the colony, resulting in the high prevalence of, and parasitic loads in, individuals of this species. In addition, three of the four endoparasite species are expected to have a direct cycle (the two oxyurids and T. bradleyi), whose transmission is facilitated by the life in burrows and host gregarious behavior. Only Pterygodermatites (Paucipectines) sp. is expected to have an indirect cycle, using scavenger insects as intermediate hosts (LUONG \& HUDSON, 2012). The singular pattern observed in $O$. degus, i.e., high prevalence and parasitic load, would indicate that its parasite assemblage is well adapted and probably no additional parasites would be detected. However, the rarefaction analysis shows that additional sampling effort could increase its parasite richness. This result supports the idea of using rarefaction analyses as a statistical tool to estimate the minimal sample size required and, therefore, to assess the study robustness.

It has been described that $P$. darwini individuals aggregate only under low-temperature conditions (thereby decreasing thermoregulation energy costs). Under high-temperature conditions, they neither use nests nor huddle. Information about $A$. olivaceus' behavior is scarce in the literature. This species is a mainly solitary rodent that builds rudimentary nests only during the breeding season, having low chances of transmitting endoparasitic infection of direct life cycle parasites from one individual to another (MUNOOZ-PEDRERO \& GIL, 2009). This is consistent with the fact than $S$. phyllotios was the only species of direct life cycle among its helminths. Although $\mathrm{H}$. gigantea is also a species with a direct life cycle, frequently found in $O$. degus, it seems to be rather an accidental parasite in A. olivaceus, based in the fact that this helminth has not been previously found in this cricetid species (CATTAN et al., 1992; LANDAETA-AQUEVEQUE et al., 2018). Thus, helminth prevalence of $A$. olivaceus and $P$. darwini depends rather on the intermediate host parasite prevalence, and in the encounter rate between infected intermediate hosts and these rodent species.

The prevalence of endoparasitic infection may also be mediated by the species lifespan; $A$. olivaceus and $P$. darwini are rodents with short lifespans, while $O$. degus has a long lifespan (MESERVE et al., 2011), meaning that the latter species has more time to become infected throughout its life course. Nevertheless, other methodological limitations could partially explain our results. For instance, small mammal sampling was performed in consecutive years, therefore, inter-annual abiotic differences among rodent populations could have influenced the detected prevalence patterns. Results of our study could serve as a basis for spatio-temporal surveys in a global change context and/or comparisons with other areas. Additional ecological studies on the life cycle and requirements of the helminth species, and on the role intermediate hosts plays in a semiarid Mediterranean ecosystem are still necessary. 


\section{Acknowledgements}

The authors thank A. Bacigalupo, R. Cares, J.P. Correa, M.I. Donoso, C. Jiménez, N. Lártiga, A. López, V. Manríquez, M. Martínez, L. Moreno, E. Oda, N. Peńa, T. Poch, M. Puebla, P. Ramírez and G. Rojo for helping during field data collection. We specially thank Esteban San Juan for helping with Figure 1. We thank CONAF-Illapel for logistic support. This work was supported by CONICYT-FONDECYT (grants No 1170367, No 11170294), and CONICYT Fellowship (grants No 221320205, No 24110058).

\section{References}

Alcaíno H, Gorman T. Parásitos de los animales domésticos en Chile. Parasitol Día 1990; 23(1-2): 33-41.

Álvarez V. Presencia de Linguatula serrata Froelich, 1789, en Dusycion culpaeus y de formas ninfales en Octodon d. degus y Abrocoma b. benetti. Bol Chil Parasitol 1960; 15: 22. PMid:13793027.

Babero BB, Cattan PE, Cabello C. Trichuris bradleyi sp. n., a whipworm from Octodon degus in Chile. J Parasitol 1975; 61(6): 1061-1063. http:// dx.doi.org/10.2307/3279376. PMid:1195067.

Babero BB, Cattan PE. Helmintofauna de Chile: III Parásitos del roedor degú, Octodon degus Molina, 1782, con la descripción de tres nuevas especies. Bol Chil Parasitol 1975; 30(3-4): 68-76. PMid:1212283.

Bush AO, Lafferty KD, Lotz JM, Shostak AW. Parasitology meets ecology on its own terms: Margolis et al. revisited. J Parasitol 1997; 83(4): 575583. http://dx.doi.org/10.2307/3284227. PMid:9267395.

Cattan PE, Núñez H, Yáñez J. Comunidades de parásitos en roedores: Una comparación entre octodontinos y cricétidos. Bol Mus Nac Hist Nat 1992; 43: 93-103.

Cofré H, Vilina Y. Diversidad de especies: mamíferos terrestres. In: Comisión Nacional del Medio Ambiente - CONAMA. Biodiversidad de Chile: patrimonio y desafíos. Santiago: Ocho Libros editores Ltda; 2008. p. 227-233.

Colwell RK, Chao A, Gotelli NJ, Lin SY, Mao CX, Chazdon RL, et al. Models and estimators linking individual-based and sample-based rarefaction, extrapolation and comparison of assemblages. J Plant Ecol 2012; 5(1): 3-21. http://dx.doi.org/10.1093/jpe/rtr044.

Colwell RK, Mao CX, Chang J. Interpolating, extrapolating, and comparing incidence-based species accumulation curves. Ecology 2004; 85(10): 2717-2727. http://dx.doi.org/10.1890/03-0557.

Colwell RK. EstimateS: statistical estimation of species richness and shared species from samples [online]. 2005 [cited 2014 Jul 11]. Available from: http://viceroy.colorado.edu/estimates/

Denke AM, Murúa R. Description of Stilestrongylus manni n. sp. (Nematoda: Heligmosomidae) parasite de différents Cricétidés du Chili. Bull Mus Natl Hist Nat Paris 1977; 298: 127-131.

Fulk GW. Notes on the Activity, Reproduction, and Social Behavior of Octodon degus. J Mammal 1976; 57(3): 495-505. http://dx.doi. org/10.2307/1379298.

Iriarte A. Mamiferos de Chile. Barcelona: Editorial LYNX; 2008.
Lacher TEJ, Mares MA. The structure of Neotropical mammal communities: an appraisal of current knowledge. Rev Chil Hist Nat 1986; 59: 121-134.

Landaeta-Aqueveque C, Henríquez A, Cattan PE. Introduced species: domestic mammals are more significant transmitters of parasites to native mammals than are feral mammals. Int J Parasitol 2014a; 44(3-4): $243-$ 249. http://dx.doi.org/10.1016/j.ijpara.2013.12.002. PMid:24486999.

Landaeta-Aqueveque C, Robles M, Henríquez A, Yáñez-Meza A, Correa J, González-Acuña D, et al. Phylogenetic and ecological factors affecting the sharing of helminths between native and introduced rodents in Central Chile. Parasitology 2018; 145(12): 1570-1576. http://dx.doi. org/10.1017/S0031182018000446. PMid:29886859.

Landaeta-Aqueveque CA, Notarnicola J, Correa JP, Yáñez-Meza A, Henríquez A, Cattan PE, et al. First record of Litomosoides pardinasi (Nematoda: Onchocercidae) in native and exotic rodents from Chile. Rev Mex Biodivers 2014b; 85(4): 1032-1037. http://dx.doi.org/10.7550/ rmb.44711.

Landaeta-Aqueveque CA, Robles MDR, Cattan PE. Helmintofauna del roedor Abrothrix olivaceus (Sigmodontinae) en áreas sub-urbanas de Santiago de Chile. Parasitol Latinoam 2007a; 62(3-4): 134-141. http:// dx.doi.org/10.4067/S0717-77122007000200006.

Landaeta-Aqueveque CA, Robles MDR, Cattan PE. The community of gastrointestinal helminths in the housemouse Mus musculus, in Santiago, Chile. Parasitol Latinoam 2007b; 62(3-4): 165-169.

Lima M, Previtali MA, Meserve PL. Climate and small rodent dynamics in semi-arid Chile: the role of lateral and vertical perturbations and intra-specific processes. Clim Res 2006; 30(2): 125-132. http://dx.doi. org/10.3354/cr030125.

Luong LT, Hudson PJ. Complex life cycle of Pterygodermatites peromysci, a trophically transmitted parasite of the white-footed mouse (Peromyscus leucopus). Parasitol Res 2012; 110(1): 483-487. http://dx.doi.org/10.1007/ s00436-011-2542-x. PMid:21766236.

Margolis L, Esch GW, Holmes JC, Kuris AM, Schad G. The use of ecological terms in parasitology (report of an ad hoc committee of the American Society of Parasitologists). J Parasitol 1982; 68(1): 131-133. http://dx.doi.org/10.2307/3281335.

Meserve PL, Kelt DA, Previtali MA, Milstead WB, Gutiérrez JR. Global climate change and small mammal populations in north-central Chile. J Mammal 2011; 92(6): 1223-1235. http://dx.doi.org/10.1644/10MAMM-S-267.1.

Muñoz-Pedrero A, Gil C. Orden Rodentia. In: Muñoz-Pedrero A, Yáñez J. Mamíferos de Chile. Valdivia: Cea Ediciones; 2009. p. 93-157.

Poupin A. Trichina spiralis en Chile. Rev Chil Hij 1897; 12: 325-374.

Quentin JC, Babero BB, Cattan PE. Helminthofaune du Chili. VSyphacia (Syphacia) phyllotios n. sp., nouvel Oxyure parasite d'un Rongeur Cricétidé au Chili. Bull Mus Natl Hist Nat Paris 1979; 4(1): 323-327.

Quentin JC, Courtin SS, Fontecilla JA. Octodonthoxys gigantea n. gen. n. sp. Nuevo namátodo Oxyurinae parásito de un roedor cavimorfo de Chile. Bol Chil Parasitol 1975; 30(1-2): 21-25. PMid:1174419.

Ramos M, Lanfranco D, Holmqvist C, Rodríguez A. Patrones de riqueza y diversidad de especies en un ensamble de pompílidos (Hymenoptera: Pompilidae) del bosque siempreverde templado Valdiviano, capturados con trampa Malaïse. Gayana 2012; 76(1): 62-66. http://dx.doi.org/10.4067/ S0717-65382012000200008. 
Ruiz del Rio A. Contribución al estudio de las enfermedades parasitarias humanas transmitidas por las ratas en Concepción. Bol Soc Biol Concepc 1939; 13: 47-82.

Sikes RS, Gannon WL. Guidelines of the American Society of Mammalogists for the use of wild mammals in research and education. JMammal 2011; 92(1): 235-253. http://dx.doi.org/10.1644/10-MAMM-F-355.1. PMid:29692469.

Sokal RR, Rohlf FJ. Biometry: the principles and practice of statistics in biological research. New York: WH Freeman; 1995.
Wells K, O'Hara RB, Morand S, Lessard JP, Ribas A. The importance of parasite geography and spillover effects for global patterns of host-parasite associations in two invasive species. Divers Distrib 2015; 21(4): 477-486. http://dx.doi.org/10.1111/ddi.12297.

Young HS, Parker IM, Gilbert GS, Guerra AS, Nunn CL. Introduced species, disease ecology, and biodiversity-disease relationships. Trends Ecol Evol 2017; 32(1): 41-54. http://dx.doi.org/10.1016/j.tree.2016.09.008. PMid:28029377. 